\title{
11
}

\section{American grand strategy in the post-Cold War era}

\author{
Hal Brands
}

The post-Cold War era has now lasted more than a quarter-century. ${ }^{1}$ This period has been an eventful time in US grand strategy. The United States did not withdraw from the world after the Soviet collapse; rather, it recommitted to pursuing a globalism every bit as ambitious as during the bipolar era. It is therefore worth considering what insights the experience of the post-Cold War era have to offer at a time when the international order is often thought to be reaching a new inflection point.

Unfortunately, discussions of the United States' post-Cold War grand strategy are afflicted by three pervasive misconceptions: first, that with the end of the Cold War the United States broke dramatically with its previous grand strategic tradition and undertook a radically new approach to the world; second, that the United States' post-Cold War grand strategy

1 The ideas expressed in this chapter were originally published in Hal Brands, 'US grand strategy: Not so bad after all', American Interest 12, no. 3, 2017, pp. 6-17; and in Chapter 1 of Hal Brands, American Grand Strategy in the Age of Trump, Brookings Institution Press, Washington, DC, 2018. I am grateful to Adam Garfinkle and the American Interest for granting permission to publish a modified version of that article here. 
has been ineffective and even quixotic; and third, that this period of US primacy is now over and that the United States has no choice but to retrench fundamentally as a result. ${ }^{2}$

All three ideas are more myth than reality. The United States did not embrace a radically new grand strategy after the Cold War; it simply adapted its long-standing, post-war grand strategy to a more favourable era of US dominance. That endeavour was hardly fruitless or self-defeating; on balance, it helped to ensure that the post-Cold War system has so far been more stable, liberal and congenial to US interests than many leading observers predicted a quarter-century ago. Finally, although Washington currently faces greater challenges to its international superiority than at any time since the Cold War, the age of US primacy has not yet passed. Accordingly, the time has not come for radical retrenchment; the proper course is rather to sustain the grand strategy that the United States has pursued, fairly successfully, for more than 25 years.

We often see the end of the Cold War as a fundamental point of departure in US foreign relations. ${ }^{3}$ Yet, in reality, the United States' post-Cold War grand strategy is best seen as the logical extension of an approach that originated following World War II. For US officials, World War II demonstrated the basic interdependence of the world environment and the corresponding need to define national security in global terms. Accordingly, the post-war decades saw a sustained US activism meant to construct an overarching international order that would be congenial to the security of the United States as well as its liberal values.

Throughout the post-war era, US officials consistently promoted an open, liberal economy, and they sought to preserve a peaceful international environment in which democracy and human rights could flourish. They worked to create stability and security in key regions from Europe to the Middle East to East Asia and to prevent any hostile power from

2 For works expressing some or all of these ideas, see Stephen Walt, 'The end of the American era', National Interest, no. 116, 2011, pp. 6-16; John Mearsheimer, 'Imperial by design', National Interest, no. 111, 2011, pp. 16-34; Michael Mandelbaum, Mission Failure: America and the World in the Post-Cold War Era, Oxford University Press, New York, 2016; Michael Mandelbaum, 'America in a new world', American Interest 11, no. 6, 2016; Christopher Layne, 'The unipolar illusion revisited: The coming end of the United States' unipolar moment', International Security 31, no. 2, 2006, pp. 7-41.

3 This is, admittedly, a view to which I contributed in an earlier book: Hal Brands, From Berlin to Baghdad: America's Search for Purpose in the Post-Cold War World, University Press of Kentucky, Lexington, 2008. 
dominating these regions either by force or otherwise. They strove to maintain an overall global balance of power that favoured the United States and its Western allies and to contain and roll back the influence of aggressive authoritarian states. And in support of all this, the United States undertook global commitments-from security guarantees and overseas force deployments to leadership of international trade pacts and institutions - that were designed to project US influence around the world. During the Cold War, these endeavours helped foster a thriving international order in the West and to contain - and ultimately defeatMoscow's rival order in the socialist bloc. ${ }^{4}$

When the Cold War ended, then, US officials did not have to chart a radical new course in United States' foreign policy. Rather, they simply adapted the country's successful post-war grand strategy to a new age of unipolarity. The United States emerged from the Cold War with clear military, economic and diplomatic primacy and at the head of a dominant Western coalition. In these circumstances, Washington effectively doubled down on its post-war statecraft.

The long-standing goal of maintaining favourable balances of power both globally and within key regions, for instance, became one of sustaining the remarkable US and Western overmatch that the Soviet collapse had produced. The goal of fostering an environment in which democracy could flourish evolved to include more actively promoting democratic institutions in countries around the globe. The goal of creating a robust liberal economy in the non-communist world became one of promoting deeper integration in the First World while spreading market institutions into the former Second and Third worlds. And the goal of containing and ultimately defeating the Soviet Union became one of preventing any new threat-from international terrorism to nuclear proliferation and the actions of aggressive 'rogue states'-from rising to the level of the former Soviet menace or otherwise bringing the good times to an end.

In sum, the United States' post-Cold War grand strategy focused on preserving US international primacy, deepening and extending the liberal order, and suppressing any dangers that threatened to disrupt this benign international environment. This strategy was first explicitly spelled out

4 See, for instance, G. John Ikenberry, Liberal Leviathan: The Origins, Crisis, and Transformation of the American World Order, Princeton University Press, Princeton, 2011. 
in the Pentagon's 1992 Defense Planning Guidance; it was subsequently adopted - with some variation in focus, tone and emphasis-by every post-Cold War administration that followed. ${ }^{5}$

This strategy, moreover, was pursued by concrete initiatives that also represented as much continuity as change. Every post-Cold War administration emphasised maintaining the United States' globestraddling military posture as the hard-power backbone of the unipolar international order. Similarly, every post-Cold War administration preserved and even extended the United States' Cold War-era alliances and security commitments to lock in stability and US influence in key regions, and to provide the security blanket that would help sustain and extend the liberal order. With respect to the global economy, every postCold War administration continued to pursue international economic integration through institutionalisation of liberal economic practices, liberalisation of global currency and capital flows, and pursuit of freetrade agreements from North American Free Trade Agreement (NAFTA) in the early 1990s to the Trans-Pacific Partnership today. And every administration continued to contain and confront aggressive actors that threatened the smooth functioning of the international system-from Saddam Hussein's Iraq to a perpetually provocative North Korea-through economic, diplomatic and military means. Finally, even in those cases where US policy did become more assertive following the Cold Waras in the case of promoting democracy - that policy followed essential precedents set by Cold War-era initiatives from the Marshall Plan to the encouragement of liberal political reforms by the Carter and Reagan administrations. US statecraft from the early 1990s onward did not break sharply with the past; it built upon foundations laid by a successful postwar grand strategy.

None of this is to say that there was no change in US grand strategy after the Cold War or that there was perfect consistency across postCold War administrations. The United States did undertake some new endeavours in the unipolar era, the practice of humanitarian military intervention - an unaffordable luxury during the Cold War-in countries from Somalia to Libya being perhaps the most notable. After 9/11,

5 On post-Cold War grand strategy, see Hal Brands, Making the Unipolar Moment: US Foreign Policy and the Rise of the Post-Cold War Order, Cornell University Press, Ithaca, 2016; Peter Feaver and Stephen Biddle, 'Assessing strategic choices in the War on Terror', in How 9/11 Changed Our Ways of War, ed. James Burk, Stanford University Press, Stanford, 2014, esp. pp. 29-31. 
moreover, the assertiveness with which the United States pursued many of its goals jumped significantly, as manifested most clearly in the invasion of Iraq. And from George H.W. Bush to Barack Obama, US presidential administrations have differed on many things, from their rhetorical styles to their approaches to using force.

Yet focusing on these differences obscures the basic continuity of postCold War grand strategy as well as the extent to which that grand strategy has been rooted in the broader tradition of post-war statecraft. In 1950, the authors of National Security Council Report 68 (NSC-68) stated that efforts 'to foster a world environment in which the American system can survive and flourish' constituted 'a policy which we would probably pursue even if there were no Soviet threat'. ${ }^{6}$ The trajectory of US grand strategy after the Cold War showed the truth of this statement.

A second myth regarding the United States post-Cold War grand strategy is that this strategy has been quixotic and even 'disastrous' - that Washington has wasted its primacy by tilting at geopolitical windmills. ${ }^{7}$ This verdict is influenced heavily by the United States' long wars in Iraq and Afghanistan, embroilments that have ranged from unsatisfying to remarkably self-defeating in their effects. And throughout the post-Cold War period there have been mistakes of omission and commission, failures of conception and implementation, and examples of hubris and blowback in US policy. From the humiliating failure of US intervention in Somalia in 1993 to the fallout from an initially successful intervention in Libya in 2011, there is plenty to lament and criticise.

Yet doing so risks missing the forest for the trees. Because, for all its travails, US strategy has played a central role in making the post-Cold War system more stable, more liberal and more favourable to US interests than it would have been otherwise-and certainly in producing a more benign global environment than many expert observers expected in the early 1990s. Indeed, just as it is now widely accepted that US Cold War

6 National Security Council 68 (NSC-68), 'United States objectives and programs for national security', 14 April 1950, fas.org/irp/offdocs/nsc-hst/nsc-68.htm (retrieved 30 January 2018).

7 Mearsheimer, 'Imperial by design', p. 16; also Barry Posen, 'Pull back: The case for a less activist foreign policy', Foreign Affairs 92, no. 1, 2013, pp. 116-29. 
grand strategy was broadly successful despite the frustrations and failures that occurred along the way, when it comes to shaping the international system, the overall record of US post-Cold War engagement has actually been fairly impressive.

To grasp this point, think about some of the most prominent forecasts about the future of international politics made just after the Cold War's end. There were, certainly, some very sunny predictions to emerge in the late 1980s and early 1990s. But there were also some very pessimistic ones.

Most leading international relations theorists initially believed, for example, that the unipolarity the United States enjoyed following the superpower conflict was inherently unsustainable - that it would promptly cause renewed Great Power balancing and the rise of countervailing coalitions. Moreover, many such observers worried that the end of the Cold War would lead not to a stable, liberal peace but to vicious, multipolar instability. Bipolarity had suppressed sources of violence and anarchy in international affairs; bipolarity's collapse would surely unleash these influences. A revanchist Japan and Germany, the emergence of sharp security competitions in Europe and East Asia, rampant nuclear proliferation and aggressive behaviour in the world's key strategic theatres: these were among the pernicious phenomena expected to materialise after bipolarity's demise. 'We will soon miss the Cold War,' John Mearsheimer warned. 'The prospect of major crises, even wars ... is likely to increase dramatically now that the Cold War is receding into history.' ${ }^{8}$

Yet whatever the imperfections of the post-Cold War era, these dogs mostly did not bark. By most meaningful comparisons, the period since the Cold War has been a time of relative international peace, stability and liberal progress. Until very recently, for instance, Great Power tensions remained remarkably low compared to the Cold War, or to any period dating back to the Concert of Europe. Regions such as East Asia and Europe have been mostly free of interstate conflict, and German or Japanese revanchism has been conspicuously absent. Nuclear proliferation has occurred via rogue actors such as North Korea, but on the whole it has advanced much more slowly than many would have predicted.

8 John Mearsheimer, 'Why we will soon miss the Cold War', Atlantic Monthly 266, no. 2, 1990, pp. $35-50$. 
Meanwhile, democracy continued its advance after the Cold War with the number of electoral democracies growing from 76 in 1990 to 120 in the early 2000s. ${ }^{9}$ Economic integration and the spread of free markets continued, and global living standards kept rising. Not least, predictions of a rapid return to unstable multipolarity proved mistaken. Instead, the United States retained a vast economic and military lead over any competitor through the end of the millennium and beyond, and many of the world's second- and third-tier powers generally sided with, rather than against, the world's sole superpower. There remained opposition to US power, of course, some of it violent, and some of it encouraged by the United States' own policies. And from catastrophic terrorism to ethnic violence, there remained significant sources of tension and conflict in international affairs. But relative to what might have been expected, the post-Cold War period was not half bad.

There were numerous reasons for this, of course. But international politics are prominently shaped by the policies of the system's leading power, and after the Cold War the United States had as much capacity to shape the system as any other great power in modern history. And indeed, US grand strategy played an essential role in making the post-Cold War order as favourable as it has been.

The maintenance of US military presence and alliances in Europe and East Asia helped to tamp down potential instability, for instance, and keep historical powers such as Japan and Germany anchored firmly to the West. ${ }^{10}$ Likewise, the extension of US alliance commitments to Eastern Europe helped to smother incipient conflicts and security dilemmas following the breakdown of Soviet hegemony and reduced pressures for nuclear proliferation or major military build-ups by historically insecure states such as Poland or Romania. In the Balkans, the US-led military interventions that occurred in 1995 and 1999 were admittedly belated and hesitant. Yet they nonetheless helped to end ethnic cleansing in south-eastern Europe and to douse persistent conflicts before they could destabilise south-eastern Europe more broadly.

9 See Freedom House, Freedom in the World 2013: Democratic Breakthroughs in the Balance, 2013, p. 29, freedomhouse.org/report/freedom-world/freedom-world-2013.

10 This is a point conceded by some leading critics of US policy. See John Mearsheimer, 'Why is Europe peaceful today?', European Political Science 9, no. 2, 2010, pp. 387-97. 
Nor were these the only areas where US policy had such effects. In the former Soviet space, proactive US diplomacy helped to achieve the denuclearisation of Ukraine, Belarus and Kazakhstan, and dramatically reduced the danger of 'loose nukes' by helping Russian officials secure poorly guarded nuclear materials. And in dealing with international outlaws such as Iraq or North Korea, US policy helped to keep rogue regimes in check, and prevented them from dominating or further destabilising key regions. In sum, US engagement suppressed renascent geopolitical competition and upheaval in key areas, and provided the reassurance that permitted global economic integration and other positive trends to continue pushing forward.

US policy affected the contours of the post-Cold War order in other ways too. Direct US engagement helped to create and strengthen international economic institutions such as the World Trade Organization, foster an array of regional and bilateral free trade pacts, and bring the single most important non-Western economy-China-into the international economic order to an unprecedented degree. In countries from Guatemala in the early 1990s to Georgia in the early 2000s, US support helped to strengthen democratic reformers and pressure authoritarian rulers. Finally, the fact that Washington maintained relatively robust military spending during the early 1990s and after helped to ensure that the international order did not swing back towards unstable multipolarity but rather remained distinctly unipolar into the early 21 st century.

US policy was not solely responsible for these developments, but it was the common thread that tied them together. If the goal of US post-Cold War strategy was to sustain and deepen a stable, liberal order in which the United States enjoyed clear primacy, then that strategy would have to be considered—on balance—a success.

But does the United States still enjoy that primacy, and can it sustain such an ambitious strategy in the future? The answer one increasingly hears is 'no'-that the world is rapidly entering a new era of multipolarity, and that Washington has no choice but to retrench markedly as a result. ${ }^{11}$

11 Christopher Layne, 'This time it's real: The end of unipolarity and the Pax Americana', International Studies Quarterly 56, no. 1, 2012, pp. 203-13. 
This argument is not baseless, for the United States' margin of superiority has slipped from its post-Cold War peak. In 1994, the United States accounted for roughly 24.7 per cent of global gross domestic product (GDP) and 38.8 per cent of world military spending, rising to 25.2 and 40.7 per cent respectively in 2004. By 2014, those numbers had fallen to 22.4 per cent of global GDP and 33.8 per cent of world military spending. The share of global wealth and power wielded by the United States' core treaty allies had also declined-from 47.1 per cent of global GDP and 36.3 per cent of global military spending in 1994 to 39.3 and 25.9 per cent, respectively, in 2014 - as that wielded by the chief challenger to US primacy had risen dramatically. In 1994, China accounted for just 3.27 per cent of global GDP and 2.2 per cent of world military spending; by 2014 , those numbers were 11.4 and 11.4 per cent. ${ }^{12}$

As the global power gap has narrowed, Washington has also been faced with more-and arguably more severe - threats to its position than at any time since the Cold War. Great Power competition has returned as Russia and China test the contours of an order that they never fully accepted and that they now have greater capacity to challenge. Moscow and Beijing are seeking to assert primacy within their own regions; they are probing the distant peripheries of the US alliance system; they are developing military capabilities that are threatening the United States' ability to project power and uphold its security commitments in Eastern Europe and the western Pacific.

Meanwhile, the long-standing challenge of handling rogue actors has also become more difficult as those actors have become more empowered. North Korea boasts a sizeable nuclear arsenal and is reportedly developing an intercontinental strike capability. Iran is fanning sectarianism, fighting multiple proxy wars and destabilising an already disordered Middle East as it also emerges from punishing international sanctions. The Islamic State is losing ground militarily, but it has shown the capacity of non-

12 Defence spending figures in this paragraph are drawn from the Stockholm Peace Research Institute's (SIPRI) annual data on global military spending. GDP figures are drawn from Economic Research Service, US Department of Agriculture (USDA), 'GDP Shares by country and region historical', www.ers.usda.gov/data-products/international-macroeconomic-data-set/ (retrieved 30 January 2018). Figures on US allies include the North Atlantic Treaty Organization (NATO) countries plus US treaty allies in Asia and Taiwan (thanks to its quasi-ally status as enshrined in the Taiwan Relations Act). These figures were calculated at the time this article was initially published, in 2016; the SIPRI database has been periodically updated since then. 
state actors to sow chaos across a crucial region while also spreading and inspiring terrorism across the globe. In so many areas, the United States confronts rising challenges to the post-Cold War order.

The world ideological climate is becoming more contested as well. After being in retreat for decades, authoritarian regimes are becoming increasingly tenacious in pushing back against liberalising currents as the 2008-09 global financial crisis and its aftermath have raised questions about whether democracies can deliver the goods. Russia, China and other authoritarian regimes have meanwhile re-entered the global ideological competition in more significant ways, touting the virtues of centralised control and 'state capitalism' and pushing back against Western concepts of political liberalism and human rights. Even countries that are part of the US-led alliance system have regressed politically; Hungarian prime minister Viktor Orban has proclaimed the rise of the 'illiberal state' as an antidote to the weaknesses of liberal democracy. As a result of all this, the advance of electoral democracy has largely stalled over the past decade, and some analysts contend that a 'democratic recession' is underway. ${ }^{13}$

Finally, there are questions about the trajectory of the United States' own engagement with the world. The United States experienced significant real declines in defence spending from 2010 to 2017. The wars in Iraq and Afghanistan have fanned pro-retrenchment sentiment at home; Americans now seem less convinced of why the United States should retain such an assertive global strategy. According to one poll conducted in 2013, 52 per cent of Americans believed that the country should now 'mind its own business internationally and let other countries get along the best they can on their own'. ${ }^{14}$ These factors have collectively fed into a narrative of national decline more pronounced than at any time since the 1970s.

Yet if this narrative is not baseless, it is badly overstated. For the idea that the era of US primacy has passed-and that we are now entering, or have already entered, a multipolar world —is far from being true. By virtually all key metrics, the United States still has substantial leads over its closest competitors. In 2015, the United States claimed a GDP of nearly $\$ 18$ trillion, which was roughly $\$ 7$ trillion larger than China's, and

13 Larry Diamond, 'Facing up to the democratic recession', Journal of Democracy 25, no. 1, 2015, pp. 141-55.

14 Paul Lewis, 'Most Americans think US should "mind its own business" abroad, survey finds', Guardian, 3 December 2013. 
it possessed a per capita GDP roughly four times that of China. In the military realm, US annual defence spending was still nearly three times that of China. ${ }^{15}$

In fact, the United States' global lead is probably far more significant than simple numerical measures like GDP and percentage of global military spending indicate. GDP is a commonly used but highly problematic way of comparing US and Chinese economic strength. This is because it is merely a snapshot rather than a fully satisfying measure of how wealth accrues over time because it does not account for such factors as the damage that China is doing to its own long-term economic potential through the devastation of its natural environment, and because it understates important US advantages, such as the fact that US citizens own significant shares in foreign corporations. By a more holistic measure of national economic strength'inclusive wealth', which takes account of manufactured capital, human capital and natural capital - the United States was still roughly 4.5 times wealthier than China as recently as $2010 .^{16}$

The US military lead is even more extensive. As one detailed study by William Wohlforth and Stephen Brooks concludes, although China's continuing military build-up presents significant regional challenges for the United States, at the global level there is simply no comparison. The United States possesses massive advantages in high-end power-projection capabilities such as aircraft carriers, fourth- and fifth-generation tactical aircraft, nuclear-powered submarines and the Airborne Warning and Control System (AWACS). These advantages have been amassed over decades, and so it will take decades - if not longer-for China to come close to matching the United States. These metrics, moreover, do not reflect other, more intangible US advantages: the years of recent operational experience, the extraordinarily high levels of human capital, and others. As Brooks and Wohlforth write:

Rather than expecting a power transition in international politics, everyone should start getting used to a world in which the United States remains the sole superpower for decades to come. ${ }^{17}$

15 For these figures, see World Bank, 'GDP (current US\$)', data.worldbank.org/indicator/NY.GDP. MKTP.CD (retrieved 30 January 2018); World Bank, 'GDP per capita, PPP (current international \$)', data.worldbank.org/indicator/NY.GDP.PCAP.PP.CD (retrieved 30 January 2018); also the SIPRI military spending data referenced above.

16 Stephen Brooks and Willian Wohlforth, 'The rise and fall of the great powers in the twenty-first century', International Security 40, no. 3, 2015-16, pp. 7-53, esp. pp. 31-2.

17 Stephen Brooks and William Wohlforth, 'The once and future superpower: Why China won't overtake the United States', Foreign Affairs 95, no. 3, 2016, pp. 91-104, esp. pp. 91-2. 
Finally, any consideration of global power dynamics must consider the role of allies; namely, the fact that the United States has dozens whereas challengers like China and Russia have few, if any. The United States' allies give it geopolitical leverage, diplomatic influence and military access that other countries can only envy; they add enormously to the overall weight of the Western coalition. As of 2014, the United States and its core treaty allies in Asia and Europe accounted for roughly three-fifths of global wealth and global military spending - a share that was moderately diminished compared with two decades earlier but still enormously impressive. ${ }^{18}$

In sum, US primacy might ultimately vanish, but that day is still a long way off. So, rather than abandoning a grand strategy that has worked fairly well, the United States should instead work to sustain that grand strategy for a period in which its primacy remains impressive, if more contested than before.

\section{IV}

Doing so requires embracing five basic principles. First, American officials and public observers need to scope the grand strategy debate right. Every four years, there is a flurry of proposals for some 'new grand strategy for America'. Yet the United States does not need a fundamentally new grand strategy. It already has one that has worked fairly well and remains broadly consonant with global power realities today. The focus of the debate, then, should be on adapting a generally successful approach at the margins rather than coming up with something radically new from scratch.

Second, and more specifically, the United States will need to shore up the military foundation of its grand strategy by reinvesting in defence. Military power is hardly the only tool of US policy, but US military dominance has been a fundamental enabler of US global influence and international stability over the past quarter-century. And for all of the United States' globalist ambitions, maintaining that military dominance has actually been quite affordable during the post-Cold War era. At the peak of the superpower contest, US military spending consumed 10-12 per cent of

18 See the SIPRI and USDA statistics for 2014 cited in footnote 12. 
GDP; since the mid-1990s, the number has usually been between 3 and 4 per cent. In a relatively benign environment, Washington has had primacy on the cheap. ${ }^{19}$

Today, however, the United States is reaching the limits of this approach. At present, the demands on US defence dollars are becoming greater than at any time in the post-Cold War era. Yet US defence dollars became scarcer after 2010 as defence budgets fell towards 3 per cent of GDP. ${ }^{20}$ Even the more recent increases in the defence budget under the Trump Administration are unlikely to fully correct this earlier decline. These trends of increasing threat and insufficient resourcing are ultimately unsustainable — at some point, they will erode the military foundation of US grand strategy and undercut the credibility of US commitments, thereby jeopardising the stability and influence that US strategy has provided. Put another way, the United States can probably preserve an acceptable level of military primacy if it is willing to spend 4 per cent of GDP on defence and to focus that spending on investments such as the anti-access/anti-denial (A2/AD)-busting capabilities that are needed to preserve US deterrence and power projection in increasingly contested regions. It probably cannot do so at 3 per cent of GDP or below.

Third, and related, the United States needs to firm up the coalition aspect of its grand strategy by getting more out of - and diversifyingits relationships with allies and partners. Its post-Cold War primacy has always rested on its leadership of a community of capable, like-minded nations. Yet, as noted previously, the share of global wealth and power held by the United States' core treaty allies has fallen over the past two decades, from 47.1 per cent of global GDP and 36.3 per cent of global military spending in 1994 , to 39.3 per cent and 25.9 per cent, respectively, in $2014 .{ }^{21}$ US primacy might be intact, but the overall relative strength of the US-led coalition is slipping.

19 See John Lewis Gaddis, Strategies of Containment: A Critical Appraisal of American National Security Policy during the Cold War, Oxford University Press, New York, 2005, p. 393; World Bank, 'Military expenditure (\% of GDP)', data.worldbank.org/indicator/MS.MIL.XPND.GD.ZS (retrieved 30 January 2018).

20 Loren Thompson, 'Pentagon budget headed below 3\% of GDP as warfighting edge wanes', Forbes, 2 February 2015.

21 These figures are drawn from the SIPRI and USDA data cited in footnote 12. 
There are two principal pathways to addressing this challenge. One is by getting more out of existing US allies, by pushing them to embrace policies that will stretch resources further. Encouraging greater defence specialisation and resource-sharing within the North Atlantic Treaty Organization (NATO), pushing Asian and Eastern European allies to adopt more cost-effective defence strategies based on anti-access/area denial, and fostering greater multilateral ties between allies (particularly in Asia) all represent ways of getting more allied bang for the buck. Likewise, as Washington increases its own commitments to Europe and the Asia Pacific, it should make clear that additional US activity is contingent upon US allies doing more too.

Equally important, the United States should offset the relative decline of some traditional allies by building and deepening newer partnerships. Global power is not just shifting to rivals of the United States-it is also shifting to states that are formally non-aligned but are nonetheless willing to work with Washington and its allies on critical international issues. India, Brazil, Indonesia, Vietnam and the United Arab Emirates are just a few of these countries; they have forged deeper ties with the United States on issues ranging from counter-terrorism to maritime issues to regional security in the Middle East and the Asia-Pacific. By building and improving flexible partnerships with such states, the United States can position itself to sustain a global imbalance of power in support of key aspects of the international order.

Fourth, even as the United States focuses on shoring up the partnerships and power that make its grand strategy possible, it must also show great discipline in employing that power. US strategy has arguably been most successful when it has focused on preserving the basic stability and wellbeing of the international system and creating broad conditions in which political and economic liberalism can advance. Conversely, the United States has got into trouble when its immense power has encouraged strategic indiscipline via the overestimation of its ability to transform foreign societies rapidly or overreach in the use of military force. Such strategic indiscipline is invariably punished through unforeseen and unwelcome geopolitical consequences abroad and diminished public support for robust US internationalism. At a time when the US margin of superiority has eroded from its post-Cold War peak, strategic profligacy is a luxury that Washington can no longer afford. 
To be clear, maintaining strategic discipline does not mean foreswearing all uses of force. Nor does it mean forsaking the active promotion of democracy and human rights. For there are occasions in which limited, coercive uses of force are appropriate to protect US interests in key regions - think of the Balkan interventions during the 1990s. There are cases in which threats to the international order can be met only by forcethink of the Islamic State more recently. There are alliance commitments that must ultimately be backed by force when necessary. Finally, the nonmilitary aspects of democracy promotion will have a key role to play in the more competitive ideological environment that is now emerging.

But being disciplined does require a sense of limits and humility. It requires recognising the limitations of military force as a tool of political transformation in historically illiberal societies. It requires accepting that there are problems and injustices that not even a superpower can solve, and that wisdom lies in discerning where US interests are most implicated and where US power can make the critical difference. Great power must be rationed as well as exploited if it is to be effective and enduring; acknowledging this point represents a fourth principle for US strategy.

Fifth and finally, sustaining the United States' post-Cold War strategy entails persuading the American public to recommit to that strategy. The state of US opinion on that subject is currently ambiguous. Polling data indicates that public support for most key aspects of US internationalism has recovered somewhat from where it was in 2012-13 and is again at or near post-World War II averages. ${ }^{22}$ But the 2016 election cycle revealed strong support for candidates who have advocated rolling back key elements of post-Cold War (and post-World War II) grand strategy, from free trade to US alliances.

Sustaining US grand strategy will thus require more intensive political efforts. US leaders will need to take up more strongly the case for controversial but broadly beneficial policies such as free trade. They will need to articulate more fully the underlying logic of alliances and other commitments whose costs are often more visible than their benefits. Not least, they will need to make the case that the burdens the country has borne in support of that order are designed to avoid the necessity of bearing far heavier burdens if the international scene returned to a more 
tumultuous state. The success of US statecraft is often reflected in the bad things that do not happen as well as the good things that do. Making this point is essential to reconsolidating domestic support now and in the future.

\section{V}

Contrary to the common caricatures, the United States' post-Cold War grand strategy has not marked a radical departure from the country's previous statecraft; it has not been a catastrophic failure, and it has not been irrevocably overtaken by global power shifts. Rather, the United States' post-Cold War approach has been rooted firmly in its successful post-war strategic tradition, and it has been broadly effective in moulding the international system to Washington's liking. Moreover, while the global environment is becoming more contested today, that grand strategy can still be sustained if US officials embrace the proper principles. Of course, adapting an existing model is less exciting than forging a wholly new one. But this is nonetheless a worthy endeavour in view of the pretty successful record of US grand strategy over a quarter-century. 
This text is taken from New Directions in Strategic Thinking 2.0:

ANU Strategic \& Defence Studies Centre's Golden Anniversary

Conference Proceedings, edited by Dr Russell W. Glenn, published 2018 by ANU Press, The Australian National University, Canberra, Australia. 